\title{
Protective Effect of Surfactant Protein D in Pulmonary Vaccinia Virus Infection: Implication of A27 Viral Protein
}

\author{
Julien Perino $^{1}$, Nicole M. Thielens ${ }^{2}$, Erika Crouch ${ }^{3}$, Danièle Spehner ${ }^{4}$, Jean-Marc Crance ${ }^{1}$ \\ and Anne-Laure Favier ${ }^{1} *$
}

1 Laboratoire de Virologie, Institut de Recherche Biomédicale des Armées- Antenne du Centre de Recherches du Service de Santé des Armées, 38702 La Tronche cedex, France;

E-Mails: julien0012000@yahoo.fr (J.P.) ; jeanmarccrance@orange.fr (J-M.C.); favier03al@yahoo.fr (A-L.F.)

2 Institut de Biologie Structurale, CNRS, CEA, Université Joseph Fourier, Grenoble, France; E-Mail: nicole.thielens @ibs.fr (N-M.T.)

3 Dept of Pathology and Immunology, Washington University School of Medicine, Saint Louis, MO, USA; E-Mail: crouch@wustl.edu (E.C.)

4 IGBMC; CNRS, UMR 7104; Inserm U 596; Illkirch, F-67400 France; Université Louis Pasteur, Strasbourg, F-67000 France ; E-Mail: spehner@igbmc.fr (D.S.)

* Author to whom correspondence should be addressed; E-Mail: favier03al@ yahoo.fr (A-L.F.); Tel.: +33-4-76-63-97-72; Fax: +33-4-76-63-69-06.

Received: 11 February 2013; in revised form: 11 March 2013 / Accepted: 12 March 2013 /

Published: 21 March 2013

Abstract: Vaccinia virus (VACV) was used as a surrogate of variola virus (VARV) (genus
Orthopoxvirus), the causative agent of smallpox, to study Orthopoxvirus infection. VARV
is principally transmitted between humans by aerosol droplets. Once inhaled, VARV first
infects the respiratory tract where it could encounter surfactant components, such as
soluble pattern recognition receptors. Surfactant protein D (SP-D), constitutively present in
the lining fluids of the respiratory tract, plays important roles in innate host defense against
virus infection. We investigated the role of SP-D in VACV infection and studied the A27
viral protein involvement in the interaction with SP-D. Interaction between SP-D and
VACV caused viral inhibition in a lung cell model. Interaction of SP-D with VACV was
mediated by the A27 viral protein. Binding required Ca ${ }^{2+}$ and interactions were blocked in
the presence of excess of SP-D saccharide ligands. A27, which lacks glycosylation,
directly interacted with SP-D. The interaction between SP-D and the viral particle was also
observed using electron microscopy. Infection of mice lacking SP-D (SP-D ${ }^{-1-}$ ) resulted in 
increased mortality compared to SP-D ${ }^{+/+}$mice. Altogether, our data show that SP-D participates in host defense against the vaccinia virus infection and that the interaction occurs with the viral surface protein A27.

Keywords: orthopoxvirus; surfactant protein D; vaccinia virus; A27 protein; pulmonary infection; innate immunity; surfactant protein $\mathrm{A}$; $\mathrm{KO}$ mice; $\mathrm{Ca}^{2+}$; sugars

\section{Introduction}

Vaccinia virus (VACV) is the prototype for the Poxviridae family and the Orthopoxvirus genus which includes variola virus (VARV), the etiological agent of smallpox. Since the eradication of smallpox in 1980, vaccination was discontinued [1], resulting in a large proportion of the world population susceptible to infection and heightened concerns about the threat of VARV as a bioweapon [2]. VARV could easily be aerosolized and used for bioterrorism with significant morbidity and mortality. VARV is principally transmitted between humans by aerosol droplets. Once inhaled, VARV first infects the upper- or lower-respiratory-tract mucosa and can lead to severe systemic disease, inducing death [3-5]. However, 70\% of exposed individuals do not die of VARV infection, emphasizing the importance of the immune response and possibly the innate immune defenses against this pathogen.

The alveolar spaces and airways of the lung are lined by surfactant, which contains protein and lipid components [6-7]. One lung protein of particular interest is surfactant protein D (SP-D), an important innate immune effector with known roles in antiviral host defense to airway pathogens [8]. SP-D is a member of the collectin subfamily of C-type lectins assembled from subunits comprising a triple helical collagen domain and a C-terminal globular carbohydrate recognition domain (CRD) (Scheme 1A). This trimeric subunit can multimerize into assemblies of four or more trimers. In humans, the collectin proteins also include surfactant protein A (SP-A) (Scheme 1B) and serum mannan-bindinglectin (MBL) [8-9], and show protein domain homologies to other complement recognition proteins (L-, H- and M-ficolins). As a soluble collectin secreted into the airspaces, SP-D is mostly produced by two types of pulmonary epithelial cells, alveolar type II cells and Clara cells and participates actively in host defense when assembled as multimers. SP-D immune activity [10-11] results from its pattern recognition activity towards multiple ligands present on bacteria, fungi, or viruses [12-15].

Binding requires the SP-D CRD and $\mathrm{Ca}^{2+}$, and SP-D can bind to a variety of carbohydrates in addition to the N-linked glycans of glycoproteins [13, 16-17]. High affinity binding to saccharide ligands requires trimerization of the CRD, which is mediated by the contiguous neck domain [18]. Binding to certain ligands can be inhibited by saccharide ligands, even though the interactions do not appear to be mediated by the carbohydrate binding activity of SP-D [19-20]. In addition, SP-D binds also to fatty acids in a $\mathrm{Ca}^{2+}$-dependent manner, and binding is inhibited by glucose. Although not explained, this could reflect overlapping binding sites for carbohydrate and non-carbohydrate ligands [21].

This specific activity ultimately leads to opsonization, agglutination and clearance of pathogens via interaction with immune cells [22]. Protective roles of SP-D against various viral pathogens have been 
extensively studied, as for Influenza A virus (IAV) and respiratory syncytial virus (RSV) [23-30]. At present, there is no evidence for the involvement of the lung collectins in innate host defense against VACV.

Lung collectins are soluble pattern recognition receptors, previously demonstrated to interact with fusion proteins from different lung viral pathogens. RSV G and F glycoproteins are involved in binding of SP-D to RSV [26]. Similarly in the case of IAV, SP-D binds to the hemagglutinin (HA) [29, 31-32] by interacting with the carbohydrate residues on some IAV and eventually leading to pathogen inactivation and clearance [33]. Inhibition by SP-D correlates with the presence of several glycan attachment sites on HA. Pandemic and avian strains appear to lack susceptibility to SP-D, which contributes to their virulence. IAV expressing the HA of pandemic viruses were associated with significant pathology of the lower respiratory tract and showed a low binding activity for SP-D while virus expressing HA of a seasonal strain induced only mild disease and exhibited strong in vitro binding to SP-D [29, 34]. These studies established that the innate immune activity of SP-D is principally mediated through interaction with viral membrane glycoproteins. Vaccinia virus A27 membrane protein (also named 14-kDa fusion protein), locates on the surface of the intracellular mature virus (IMV) [35], plays an important role in virus-to-cell and cell-to-cell fusions [36-38]. This highly antigenic protein, involved in virulence of VACV, is conserved among Orthopoxvirus genus, and elicits neutralization antibodies [39]. A27 is involved in virus attachment to cell by binding glycosaminoglycans [40-41] or sulfatide [42]. Interaction with GAGs was mediated by the negative charge of the sulfate [40] that bound a stretch of positive amino acids of A27 (Lys/Arg-rich domain, residues 21-31) [41, 43]. A27 was shown to have functional properties similar to those of HA of IAV, except that the transmembrane domain is replaced by a domain involved in binding to A17 protein for membrane anchoring [44-45]. The two proteins, localized on the virus surface, form trimers in the virus particle [35] and are involved in virus penetration. The $\mathrm{NH}_{2}$-terminal region of A27 protein is implicated in virus entry by direct fusion of the virus membrane with the cell plasma membrane [38, 41] or by receptor-mediated endocytosis followed by a low $\mathrm{pH}$-induced fusion of viral and endosomal membranes [46]. Accordingly, we hypothesized that SP-D might interact with A27 and participate in the pulmonary defenses against VACV.

In addition to neutralizing virus in vitro, SP-D can enhance clearance in vivo. SP-D interacts with influenza virus [47] resulting in the increase of the virus clearance from the lung of infected animals [48-49]. Mice lacking SP-D $\left(\mathrm{SP}_{-} \mathrm{D}^{-/}\right)$and wild type mice $\left(\mathrm{SP}_{-} \mathrm{D}^{+/+}\right)$were used as a model of infection to clarify the relevance of these various in vitro studies to the physiological situation.

In the current paper, we studied the effect of collectins and particularly SP-D on VACV infection in vitro and specifically the effect of SP-D in vivo. We demonstrated that SP-D was able to reduce VACV infection and showed that the A27 virus protein was a potential partner of SP-D interaction. This study represents a first approach to the involvement of SP-D in Orthopoxvirus infection and we suggest that SP-D may be associated with innate defense against VACV. 
Scheme 1. Structure of SP-D and E321K SP-D NCRD mutant. (A) SP-D monomer (illustrating CRD, neck, collagen-like and N-terminus domains) and SP-D trimer formed by three monomers. (B) SP-D dodecamer formed by four trimers linked at the N-terminus by disulfide bonds. (C) Illustration of Neck+CRD (NCRD) with a genetically engineered S protein binding tag and His binding tag. CRD cartoons (green) representing the carbohydrate binding groove flanked by amino acid residues 325-328 and 343-349, associated $\mathrm{Ca}^{2+}$ ion (residue 321). Scheme adapted from [50].

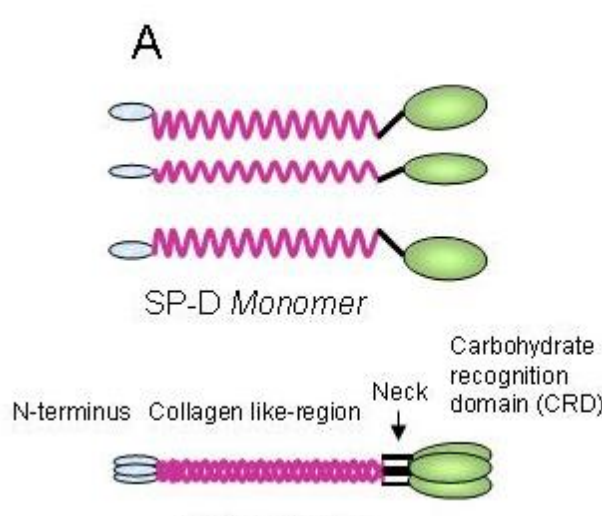

SP-D Trimer
B
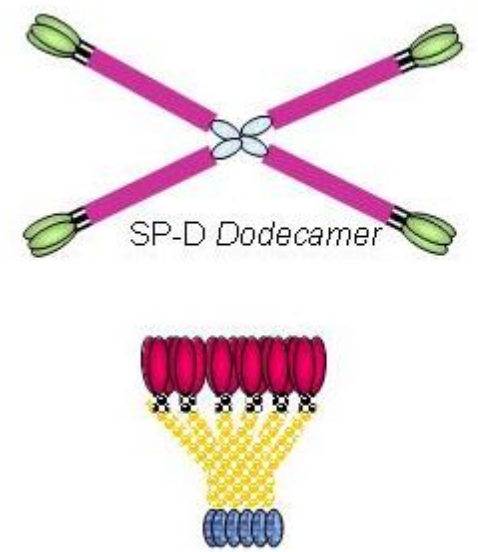

SP-A Octadecamer
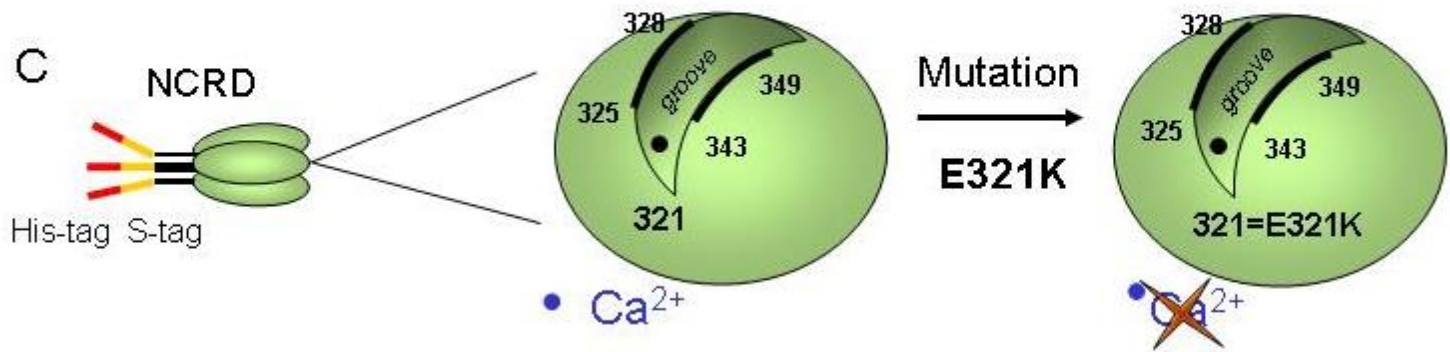

\section{Results and Discussion}

\subsection{Vaccinia virus interaction with surfactant protein $D$}

The interaction of VACV with surfactant proteins (SP) was studied using a virus-protein overlay assay (Figure 1). Solutions of purified VACV of three strains, Western-reserve, Lister and IHD-J were dotted in replicates onto nitrocellulose membranes and incubated with surfactant protein solutions. After extensive membrane washing, proteins bound to the membranes were detected using a specific anti-surfactant protein antibody (anti-SP-A and anti-SP-D) and enhanced chemiluminescence. Weak nonspecific binding was observed with the control membrane. Nonspecific signal was comparable to the signals observed with human alveolar proteinosis surfactant protein A (AP-SP-A) and human recombinant surfactant protein $\mathrm{A}(\mathrm{RhSP}-\mathrm{A})$. RhSP-D was the only protein giving a strong interaction with VACV from different strains. 
Figure 1. Binding of surfactant proteins to Vaccinia virus (VACV). Three VACV strains, VACV-WR, VACV-Lister and VACV-IHD-J, were dotted onto membranes and incubated with $2 \mu \mathrm{g}$ of various surfactant proteins. After extensive washes, bound SPs were detected with specific anti-surfactant protein antibodies and revealed by enhanced chemiluminescence (ECL). Mock membrane was incubated with specific anti-SP antibodies. RhSP-D and RhSP-A, dotted onto SP control membrane, were revealed with specific anti-SP antibodies. AP-SP-A, human SP-A from alveolar proteinosis; RhSP-A, recombinant human SP-A; RhSP-D, recombinant human SP-D.

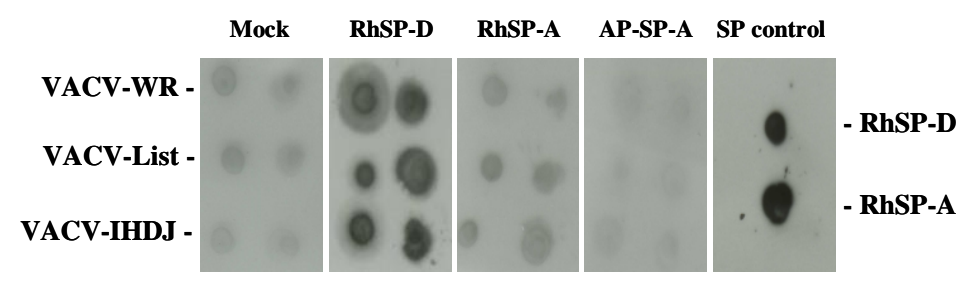

\subsection{SP-D inhibits VACV infectivity}

A plaque assay was used in order to determine consequences of SP-D interaction on virus infection. VACV-WR was pre-incubated with SP-A and SP-D proteins (Figure 2A). Under these conditions, the protein suspensions did not induce any cytotoxicity (data not shown). Bovine serum albumin did not modify the virus infection ( $\mathrm{p}>0.05$, two-tailed unpaired Student's t-test). Pre-incubation of VACV-WR with AP-SP-A or with RhSP-A had no neutralizing activity as observed in the plaque assay ( $\mathrm{p}>0.05$, two-tailed unpaired Student's t-test). By contrast, incubation of virus with SP-D resulted in strong viral neutralizing activity (53\%) when compared with non pre-incubated virus $(\mathrm{p}<0.0001$, two-tailed unpaired Student's t-test). To characterize SP-D-virus interaction, increasing concentrations of RhSP$\mathrm{D}(0.15,0.30$ and $0.60 \mu \mathrm{g} / \mathrm{mL})$ were pre-incubated with the same amount of VACV (Figure 2B). No inhibition of infection was observed with bovine serum albumin while RhSP-D induced a statistically significant dose-dependent inhibition of VACV-WR from 0.15 to $0.60 \mu \mathrm{g} / \mathrm{mL}$ ( $\mathrm{p}=0.0033, \mathrm{p}=0.0001$ and $\mathrm{p}<0.0001$, respectively; two-tailed unpaired Student's t-test). Therefore, the activity of RhSP-D on VACV was confirmed and characterized as a dose-dependent inhibition.

\subsection{Multimeric SP-D but not NCRD domains inhibits VACV infectivity}

The inhibiting activity from full length SP-D protein was compared with trimeric NCRD domains (neck + carbohydrate recognition domain) derived from human and rat sequences (see protein structure in Scheme 1A). NCRDs were used to further characterize the requirement for multimerization of the native protein SP-D to induce viral inhibition. The human E321K mutant (mutNCRD) was previously described for its lack of HA inhibitory activity [51], resulting from the mutation of a residue involved in the coordination of calcium at the lectin site (Scheme 1C). No viral inhibition was obtained with BSA nor with any of the tested NCRD (Figure 2C) ( $>0.05$, two-tailed unpaired Student's t-test) in contrast with full length SP-D protein (53\% inhibition) ( $\mathrm{p}<0.0001$, two-tailed unpaired Student's ttest). Additional experiments performed at $10 \mu \mathrm{g} / \mathrm{mL}$ of NCRD did not induce viral inhibition (data not 
shown). In these conditions, results suggest that the NCRD domain is not sufficient and that the multimeric state of full length protein is mandatory for efficient viral inhibition.

Figure 2. Virus infection inhibition assay. VACV-WR was incubated with proteins for $1 \mathrm{~h}$. A549 cells were infected at a MOI of 0.0001 and virus replication was measured by a PFU assay. VACV-WR pre-treated groups were compared to the VACV-WR group. An asterisk indicates a statistically significant difference ( $p<0.05$, two-tailed unpaired $t$-test). Incubation (A) with $0.6 \mu \mathrm{g} / \mathrm{mL}$ of BSA, AP-SP-A, RhSP-A or RhSP-D; (B) with increasing RhSP-D doses. Symbols: $₫$, VACV-WR+RhSP-D; $\square$, VACV-WR+BSA. (C) VACV-WR was incubated with $0.6 \mu \mathrm{g} / \mathrm{mL}$ of RhSP-D and $2 \mu \mathrm{g} / \mathrm{mL}$ of NCRD domain of SP-D from human (hNCRD), rat (rNCRD), or human E31K mutant (mutNCRD) for $1 \mathrm{~h}$.
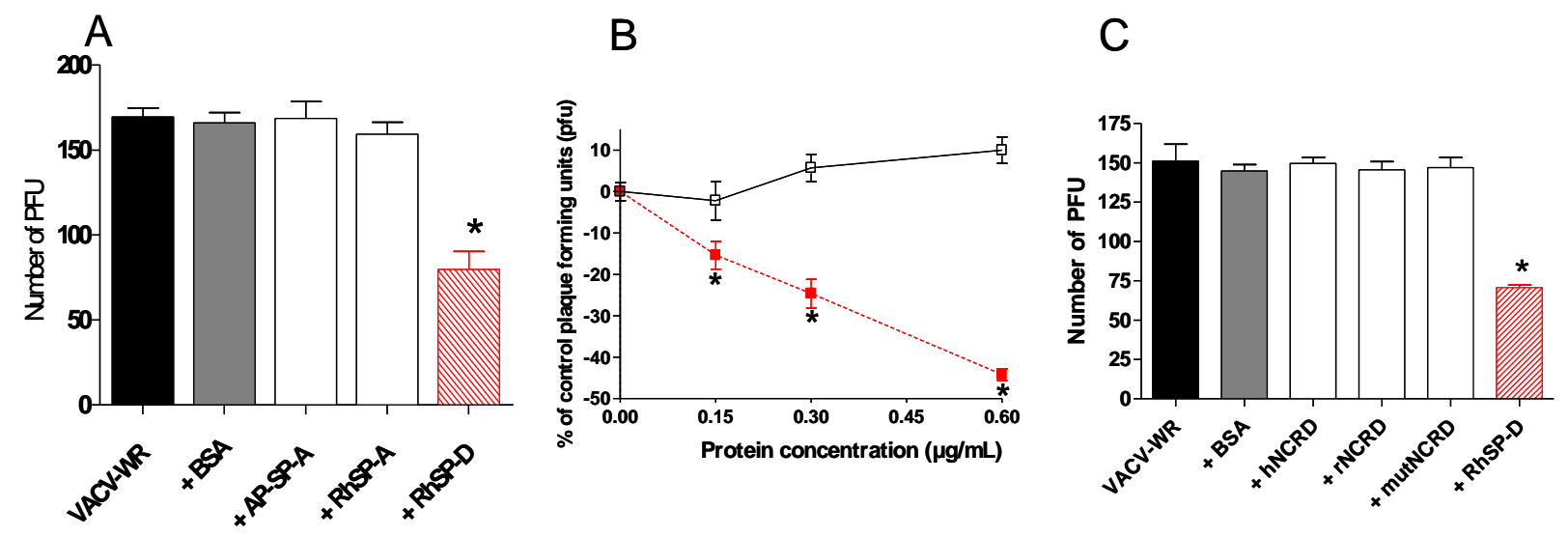

\subsection{Comparison of infection inhibiting activity of SP-D with other human defense lectins}

SP-D is belonging to collectins which are oligomeric proteins consisting of collagen stalks and globular carbohydrate recognition domains. The other collectin MBL and the related proteins L-, Hand M-ficolins were tested for viral inhibition in comparison to SP-D (Supplementary data 1). Equal quantities of proteins were tested in this experiment. SP-D was the only collectin leading to VACVWR infection inhibition (about 50\% of inhibition) ( $\mathrm{p}<0.0001$, two-tailed unpaired Student's t-test).

\subsection{Recombinant $A 27$ viral protein binds to $S P-D$}

The binding of A27 protein to SP-D was investigated in vitro using an ELISA assay. A27 viral protein is a membrane protein localized on the surface of the IMV, the most abundant virus form produced in infected cells known to be responsible for the initiation of infection. An E. coli expression system was used because A27 protein produced in this system was shown to exhibit structural and functional properties similar to those found in the virus particle and in virus-infected-cells [52]. To determine the involvement of the A27 viral protein in SP-D interaction, A27 was expressed in a soluble form in $E$. coli, and purified by nickel affinity chromatography using the hexahistidine tag at the N-terminus of the recombinant protein. As determined by SDS-PAGE analysis, in denaturing and reducing conditions A27 migrated as one band (14 kDa, monomer) detected by Coomassie blue 
staining and as two bands (an additional minor band at $20 \mathrm{kDa}$ ) that was detected by western-blotting (Figure 3A, lane 1). In non-reducing conditions, A27 spontaneously assembled into trimers (Figure 3A, lane 2). Despite the same amount of protein applied in each lane, a difference in A27 band intensities (lanes 1 and 2) was observed which may result from the weaker capacity of the monoclonal antibody to react with the monomeric state of A27. N-glycosidase F digestion experiments confirmed the expected absence of sugars (data not shown).

The interaction of SP-D with A27 was examined onto microtiter wells (Figure 3B). Coated proteins were incubated with RhSP-D. Bound RhSP-D was detected with a specific antibody against SP-D. A mix of HA of IAV was used as a positive control of interaction. RhSP-D interacted with A27 in presence of $\mathrm{Ca}^{2+}$ whereas the binding was abolished for both $\mathrm{HA}$ and $\mathrm{A} 27$ proteins, in the absence of $\mathrm{Ca}^{2+}$. The experiment indicated that the binding of SP-D to A27 is $\mathrm{Ca}^{2+}$-dependent.

Contribution of NCRD domains in the interaction between SP-D and A27 was examined in microtiter wells (Figure 3C). Coated proteins were incubated with hNCRD or mutNCRD in presence of $\mathrm{Ca}^{2+}$. Bound NCRDs were detected with a specific antibody against SP-D. A mix of HA of IAV was used as a positive control of interaction. A weak interaction was obtained for hNCRD with both A27 and HA whereas no binding of mutNCRD to HA was observed. The experiment suggested that NCRD of SP-D could contribute to the interaction with A27. The weak interaction of hNCRD with A27 was maintained with the mutNCRD, suggesting the region of the CRD near to, but distinct from, the lectin site contributed to the interaction.

We next studied whether monoclonal antibodies (mAbs) directed against the A27 protein of VACV could prevent the interaction between A27 and hNCRD, using a protein-protein overlay assay (Figure 3D). A27 solutions were dotted in replicates onto nitrocellulose membranes and incubated with hNCRD. After extensive membrane washing, bound hNCRD was detected using S protein-HRP antibody (anti-His antibody was avoided as both hNCRD and A27 were His-tagged proteins) and enhanced chemiluminescence. No binding was observed with the control spots (mAbs alone). A weak specific signal was observed with A27 and hNCRD compared to HA of IAV and hNCRD. No inhibition was observed with control mouse IgG while mAb against A27 (5B4) partially inhibited the A27-hNCRD interaction.

To clarify the finding obtained with NCRD, a higher oligomeric structure of NCRD was tested using the capacity of the multivalent $S$ protein-HRP to generate aggregates of NCRD containing the $S$ protein binding site [53] [28]. In fact, NCRD contains an S protein binding site, which can be detected by the $\mathrm{S}$ protein conjugated with HRP and subsequently used to detect the binding to various ligands. Preincubation of hNCRD with the S protein-HRP complex resulted in considerably increased binding to A27 compared to the situation where hNCRD is added to the viral protein followed by addition of S-protein-HRP (Figure 3E). A similar result was obtained with HA (data not shown), thus indicating that multivalency of NCRD is required to potentiate the interaction with A27.

Figure 3. A27 viral protein interacts with SP-D. (A) Characterization of the recombinant A27 protein. The purified recombinant A27 protein $(0.5 \mu \mathrm{g} / \mathrm{lane}$ and $2 \mu \mathrm{g} / \mathrm{lane}$ for Western-blot (left panel) and 12\% SDS-PAGE analysis (right panel), respectively) was heated at $100^{\circ} \mathrm{C}$ for $5 \mathrm{~min}$ in denaturating, reducing sample buffer (lane 1) or incubated for $5 \mathrm{~min}$ at room temperature in non-reducing sample buffer (lane 2). RhSP-D (2.5 $\mu \mathrm{g} / \mathrm{ml})$ (B) 
or hNCRD and mutNCRD $(5 \mu \mathrm{g} / \mathrm{ml})(\mathrm{C})$ were incubated for 1 hour at $37^{\circ} \mathrm{C}$ with coated proteins on 96-multiwell plate. Bound RhSP-D was revealed with a rabbit anti-SP-D specific antibody and with a goat anti-rabbit-HRP antibody. TMB substrate was added and OD was measured at $450 \mathrm{~nm}$. An asterisk indicates a statistically significant difference $(\mathrm{n}=3 ; \mathrm{p}<0.05$, two-tailed unpaired t-test). (D) Interaction between A27 and hNCRD was partially inhibited with mAbs against A27. A27 was preincubated with mAbs at $10 \mu \mathrm{g} / \mathrm{mL}$. $1 \mu \mathrm{g}$ of A27 protein was dotted onto membrane and incubated with hNCRD $(5 \mu \mathrm{g} / \mathrm{mL}) .0 .5$ $\mu \mathrm{g}$ of hNCRD was dotted onto the membrane as positive detection control. After extensive washes, bound hNCRD was detected with specific S protein-HRP antibody and revealed by enhanced chemiluminescence (ECL). (E) Both A27 protein and BSA were coated on 96-multiwell plate. A range $(2,5,7,15$ and $30 \mu \mathrm{g} / \mathrm{mL})$ of hNCRD alone or hNCRD preincubated with $\mathrm{S}$ protein-HRP (1:20, concentration) was incubated for 1 hour at $37^{\circ} \mathrm{C}$. Preincubation of hNCRD with S protein-HRP noticeably increased binding of hNCRD to A27. BSA, bovine serum albumin; HA, hemagglutinin of IAV; A27, A27 viral protein of $\mathrm{VACV}$ (14-kDa fusion protein). Incubation was performed in the absence (-) or presence $(+)$ of $5 \mathrm{mM} \mathrm{Ca}^{2+}$.

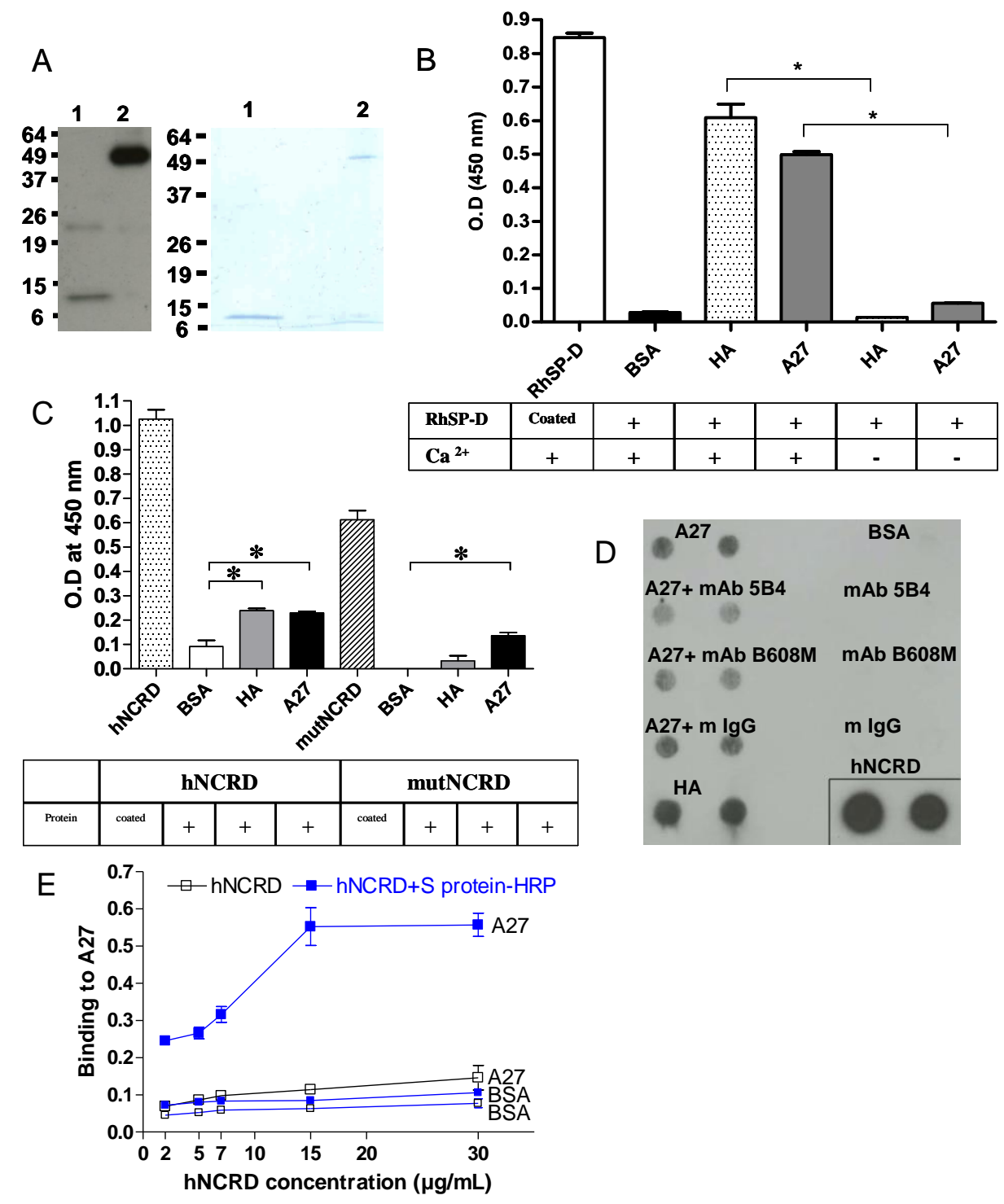




\subsection{Visualization of the interaction of $S P-D$ to VACV particle by electron microscopy (EM)}

To further study the interaction between SP-D and VACV viruses, electron microscopy was performed on inactivated VACV-WR incubated with RhSP-D (Figure 4). After negative staining, the VACV particles were observed by EM (Figure 4A). The electron micrographs showed the polymeric forms of RhSP-D as previously described for both bronchoalveolar lavage purified SP-D and RhSP-D as "astral bodies" [54-55]. Preparation contained only some dodecamers (cruciform structures) and a majority of higher order multimers of RhSP-D (Figure 4B). The globular heads of SP-D, containing the CRD, can be seen especially on the periphery of the radially symmetric multimers. In presence of the virus particle, no interaction was observed with SP-A (data not shown) whereas SP-D interacted with the surface of the virus particle, which binds at one part of the virus particle (Figure 4C).

Figure 4. Electron Microscopy of virus particle interacting with SP-D. The interaction between inactivated VACV-WR and RhSP-D was illustrated. Panel A represents the inactivated virus. Panel B represents the control of RhSP-D (arrows: dodecamer, cruciform structure; and arrow heads: higher order multimers). Panel $\mathrm{C}$ displays the interaction and the site of attachment (arrows) between VACV-WR and RhSP-D; arrow heads represent isolated protein. The bar corresponds to $100 \mathrm{~nm}$.

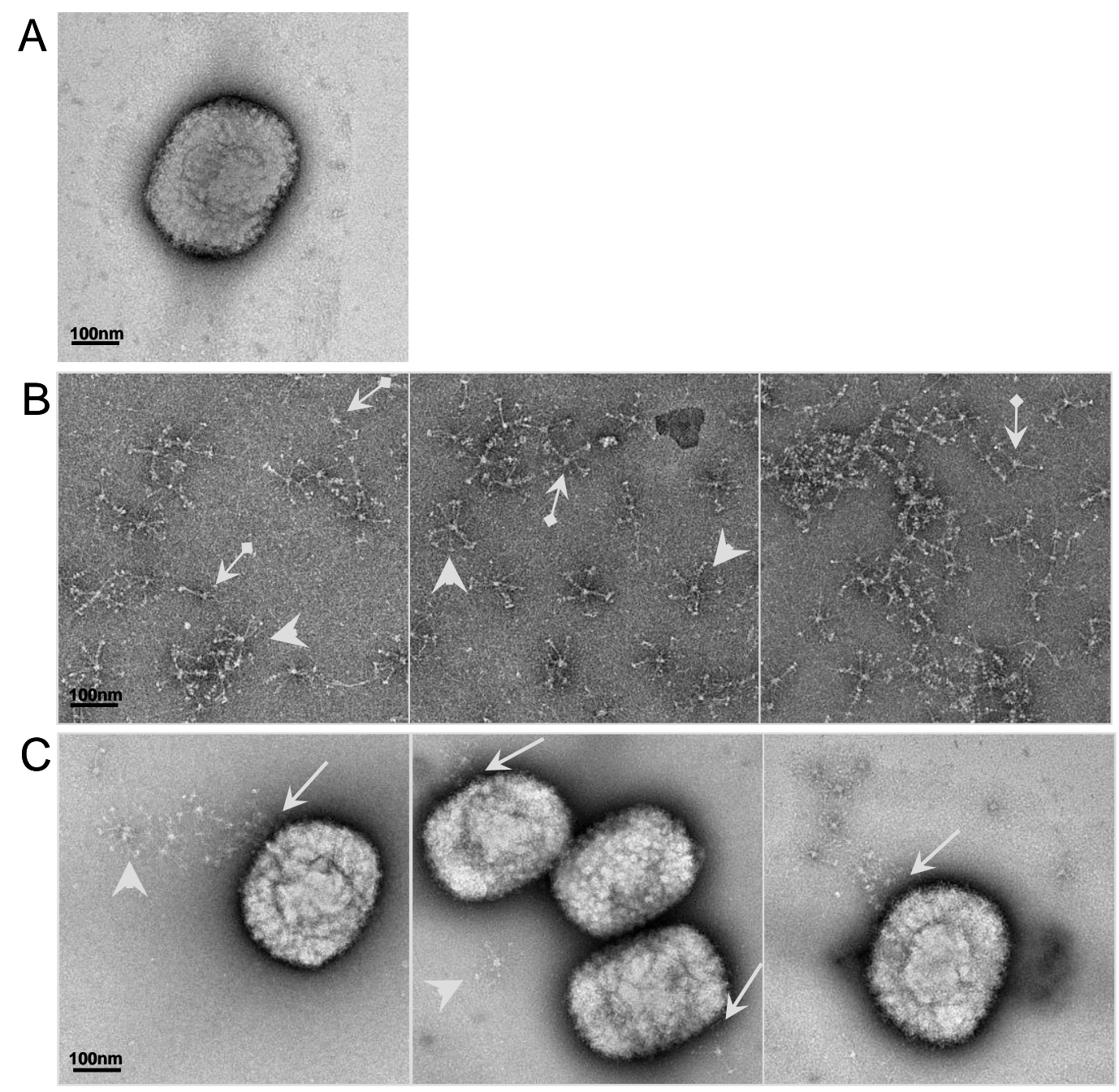




\subsection{Analysis of SP-D binding to VACV by surface plasmon resonance (SPR) spectroscopy}

\subsubsection{SP-D binding to viral particle}

SPR spectroscopy was used to further characterize the interaction of SP-D with VACV. First, the well characterized interaction between HA of IAV and SP-D was verified by SPR, allowing for confirmation of previous studies using other techniques [23, 31, 47]. Soluble HA bound in a dosedependent manner to immobilized SP-D in the presence of calcium ions (Figure 5A). Kinetic analysis of these binding data yielded association and dissociation rate constants of $0.7 \times 10^{5} \mathrm{M}^{-1} \mathrm{~s}^{-1}$ and $1.2 \mathrm{x}$ $10^{-4} \mathrm{~s}^{-1}$ respectively, using global fitting to a 1:1 Langmuir interaction model. The deduced apparent equilibrium dissociation constant $\left(K_{\mathrm{D}}\right)$ was $0.53 \mathrm{nM}$, indicative of high affinity. However, due to the oligomeric nature of both SP-D and HA, it cannot be excluded that some rebinding might occur during the dissociation phase, thus enhancing the apparent stability of the complex. Inhibition of the interaction between HA and SP-D was obtained using maltose and EDTA (Figure 5B).

Injection of various concentrations of iVACV over immobilized SP-D (Figure 5C), yielded dosedependent responses ranging from 50 to 200 resonance units using equivalent titers of iVACV ranging from $2.10^{8}$ to $2.10^{9}$ virus $/ \mathrm{mL}$ (corresponding to $1 / 100$ and $1 / 10$ dilutions, respectively). The affinity of the interaction could not be quantified since determination of the dissociation constant requires precise knowledge of the molar concentration of the soluble interactant, which does not apply to a viral particle with many surface-exposed potential ligands. Using a fixed viral dose $\left(D=1.10^{9}\right.$ equivalent titer of inactivated virus $/ \mathrm{mL}$ ), different potential inhibitors were tested (Figure 5D). Inhibitors of specific CRD attachment, maltose, mannose and mannan induced 32\%, 36\% and 53\% of inhibition at this specific dose, respectively. The calcium chelator induced a strong inhibition of $78 \%$ (Figure 5D). These results showed the calcium-dependence of the interaction between VACV and SP-D and the inhibitory effect of sugar ligands of SP-D, thus strongly suggesting the involvement of the carbohydrate-binding domain of the collectin.

\subsubsection{Characterization of the interaction between SP-D and recombinant A27}

HA of IAV was demonstrated to strongly interact with SP-D (see Figure 5A), moreover it was shown to present common domains and function with A27 vaccinia virus protein [35]. To determine A27 protein involvement in SP-D interaction with VACV, trimeric recombinant A27 was immobilized on a sensor chip and binding of SP-D to A27L analyzed using SPR spectroscopy (see Figure 5E). SP$\mathrm{D}$ bound to $\mathrm{A} 27 \mathrm{~L}$ in a dose-dependent manner and the dissociation was very slow, reflecting the great stability of the complex (Figure 5E). Determination of the kinetic parameters yielded $k_{\mathrm{a}}$ and $k_{\mathrm{d}}$ values of $5.8 \times 10^{5} \mathrm{M}^{-1} \mathrm{~s}^{-1}$ and $8.9 \times 10^{-5} \mathrm{~s}^{-1}$, with a resulting apparent $K_{\mathrm{D}}$ value of $0.15 \mathrm{nM}$, indicative of strong affinity. Again, these values are only apparent due to the multivalent nature of the interaction, but they are in the same range as those obtained for the interaction of HA with SP-D under the same conditions. Inhibition of interaction was also observed in the presence of maltose and EDTA (Figure $5 \mathrm{~F})$. 
Figure 5. SPR analysis of the interaction of VACV with immobilized SP-D. VACV-WR particle binding to SP-D: (A) SPR analysis of the interaction of HA with immobilized SPD. HA of IAV was injected at concentrations of $0.5,1,2,3,5$ and $8 \mathrm{nM}$ over immobilized SP-D. (B) HA (3 $\mathrm{nM}$ ) was injected over immobilized SP-D in the presence of selected competitors of SP-D-ligand interaction ( $5 \mathrm{mM}$ maltose or $3.4 \mathrm{mM}$ EDTA). (C) iVACV was injected at various concentrations ranging from equivalent titer $2.10^{8}$ to $2.10^{9}$ virus $/ \mathrm{mL}$ (corresponding to $1 / 100$ to $1 / 10$ dilutions, respectively) over immobilized SP-D. (D) iVACV (1/20 dilution) was injected over immobilized SP-D in the presence of competitors of SP-D interaction with carbohydrates $(10 \mathrm{mM}$ maltose, $10 \mathrm{mM}$ mannose, $100 \mu \mathrm{g} / \mathrm{mL}$ mannan or $3.4 \mathrm{mM}$ EDTA). All results are representative of two independent experiments. Sensorgrams were distorted at the beginning and end of injections due to solvent effect. Binding of SP-D to viral A27 protein: (E) Purified SP-D was injected at concentrations of 1.7, 3.4, 6.8, 9.1 and $13.7 \mathrm{nM}$ over immobilized A27. (F) SP-D (6.8 nM) was injected over immobilized A27 in the presence of $5 \mathrm{mM}$ maltose or $3.4 \mathrm{mM}$ EDTA. Results are representative of two independent experiments.

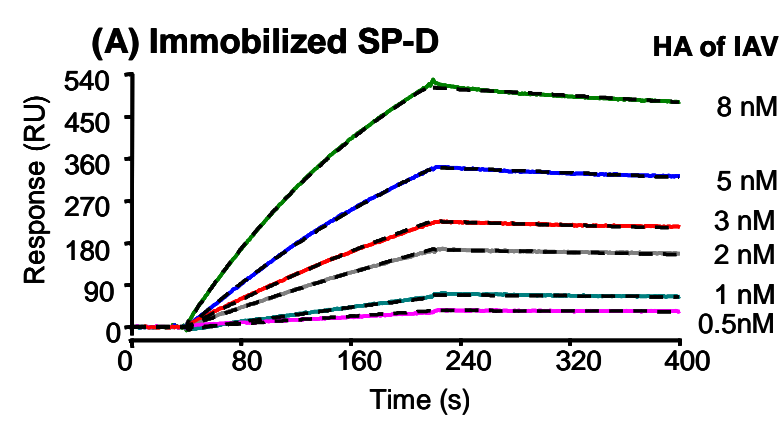

(C) Immobilized SP-D

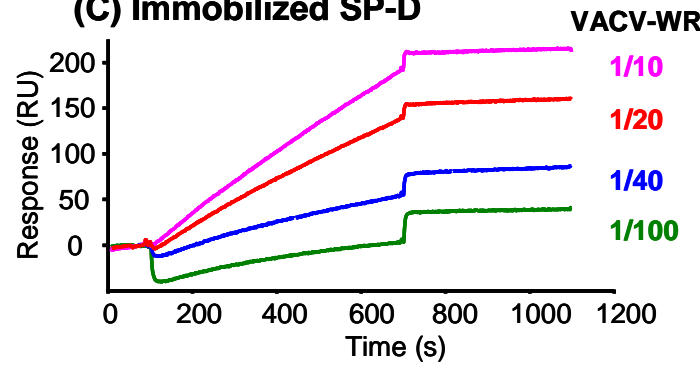

(E) Immobilized A27

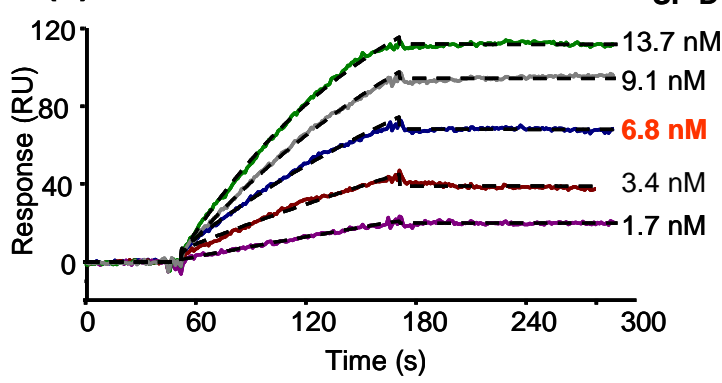

\section{(B) Immobilized SP-D}
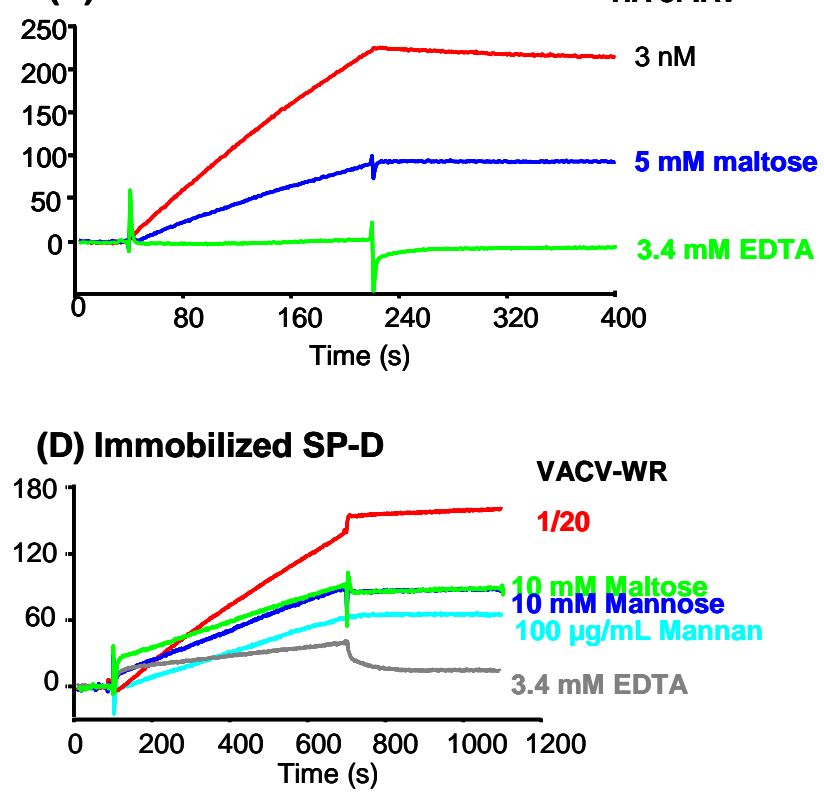

(F) Immobilized A27 SP-D

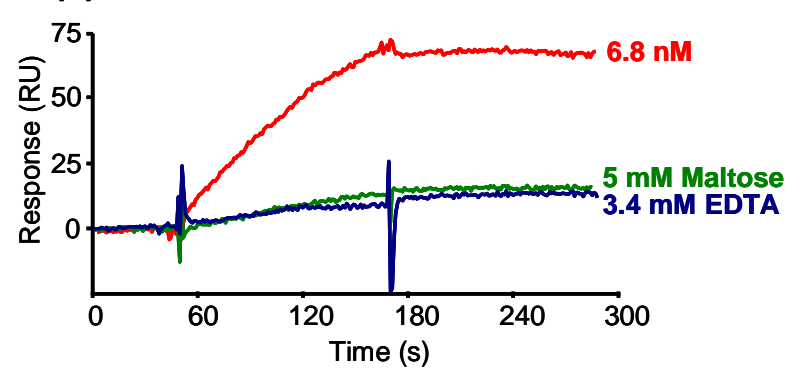


2.7.3. Characterization of the interaction of A27 with other proteins of the defense collagen family

The capacity of other proteins of the defense collagens family to interact with A27L was tested by monitoring binding of the proteins to immobilized A27 using SPR spectroscopy (Supplementary data 1B). As shown in the upper panel, all proteins tested bound to A27, although clearly to different extents: the binding level for MBL was in the same range as that of SP-D, whereas the three human ficolins, especially $\mathrm{M}$ - and $\mathrm{H}$-ficolins, exhibited poor A27 binding capacity. We decided next to determine if the NCRD domain from SP-D was sufficient to mediate interaction with A27 (Supplementary data 1B, lower panel). Human NCRD (hNCRD) and E321K, a mutant NCRD (mutNCRD) with impaired binding capacity to a variety of microorganisms recognized by SP-D [50] showed a weak interaction with A27. When using a $90 \mathrm{nM}$ concentration of hNCRD, a weak interaction was detected. However, similar results were obtained at a concentration of $900 \mathrm{nM}$ thus casting doubts about the specificity of the observed interaction (data not shown). Both SP-A (RhSP-A and AP-SP-A) showed no interaction with A27 (lower panel). Among the tested lectins, SP-D showed the strongest interaction with A27. Because trimeric NCRD was inactive, the data suggest important cooperative interactions among CRDs.

\subsection{Protective role of SP-D in VACV infection in mice model}

To address the role of SP-D in VACV susceptibility in vivo, $\mathrm{SP}_{-} \mathrm{D}^{+/+}$and SP-D ${ }^{-/-}$(deficient in SP-D) were infected with VACV-WR by intranasally instillation. The VACV-WR strain, shown to bind SP-D in vitro, was chosen because of its ability to induce death in mice [56]. $\mathrm{LD}_{50}$ calculated on SP-D ${ }^{+/+}$ mice was estimated at $5 \times 10^{5} \mathrm{PFU}$ (data not shown). The experiment was performed three times with comparable and significant results, one representative experiment being shown (Figure 6). At $1 \mathrm{LD}_{50}$ inoculating dose, VACV-WR was responsible for about $50 \%$ death of SP-D ${ }^{+/+}$mice whereas all uninfected animals survived. Difference in survival was observed between VACV-infected SP-D ${ }^{+/+}$ and VACV-infected SP-D ${ }^{-/-}$mice groups. In the absence of SP-D, the pathogenesis of VACV was increased, only $23 \%$ infected SP-D ${ }^{-/}$mice survived compared to $50 \%$ in the infected SP-D ${ }^{+/+}$mice group ( $\mathrm{p}=0.0069 ;$ Log Rank test).

The importance of the lung as a primary target during respiratory transmission of variola virus highlighted the importance to study influence of surfactant during infection [42]. It is likely that lung surfactant defense proteins play a role in containing the beginning of the infection [23]. Surfactant innate defense system is mainly composed of collectins and phagocytes. Collectins or C-type lectins are composed of polypeptides including mannan-binding lectin, bovine conglutinin and two surfactant proteins: SP-A and SP-D. This family shares structural features such as a collagenous $\mathrm{N}$-terminal domain, a neck and a globular C-terminal domain which is implicated in carbohydrate recognition leading to pathogens opsonization and clearance [57]. 
Figure 6. SP-D protected mice against VACV-WR. Five week old Black Swiss mice SP$\mathrm{D}^{+/+}$and SP-D ${ }^{-/-}$were infected intranasally with $1 \mathrm{LD}_{50}$ of VACV-WR. Survival was monitored for 17 days. SP-D ${ }^{-/-}$group was compared to SP-D ${ }^{+/+}$group and to a mockinfected group (Log Rank test).

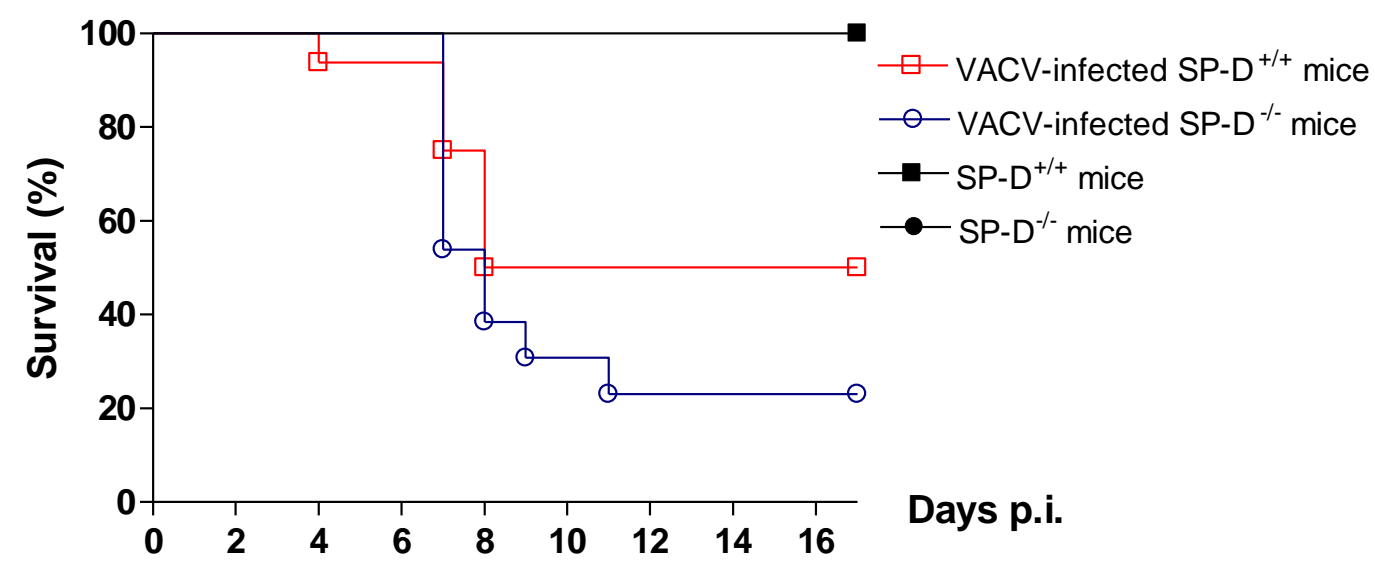

This study provides the first evidence for an inhibitory effect of SP-D on poxvirus infectivity in vitro and its exclusive activity compared to other collectins. Among pulmonary collectins, SP-D was the only protein leading to a strong interaction with VACV in our study. Three strains of VACV were tested (Western Reserve, Lister and IHD-J) and no difference was observed. SP-A (recombinant and alveolar proteinosis purified forms) was unable to interact with any viral strain contrary to SP-D, which strongly interacted with all strains in a similar manner. These results demonstrated a specificity of binding between SP-D and VACV contrary to Influenza A Virus (IAV) that interacts with both SPA and SP-D [47, 58].

Using a pulmonary cell line, this interaction was directly linked to the ability of SP-D to inhibit virus infection when using a pre-incubation plaque assay. Implication of Neck + Carbohydrate Recognition Domain (NCRD) was tested but no inhibition was obtained with any of the two recombinant NCRD domains (human and rat). This result indicates that purified NCRD alone is not sufficient but may require higher level of organization (multimerization) for being active or that full length protein is needed for inhibition activity. A similar result was previously described for IAV, with native SP-D being protective in vivo but not wild-type NCRD alone [53] [28]; however, certain mutant NCRDs with greatly enhanced IAV binding activity did show antiviral activity in vivo [59-60].

Influenza A virus is one of the most extensively respiratory virus studied. Its interaction with SP-D was widely studied and authors agreed that HA mediated-interaction is sugar inhibited and Cadependent, resulting from the involvement of CRD. While we could confirm these observations between for HA of IAV by ELISA and SPR spectroscopy, we could not completely elucidate the mechanism of interaction between A27 and SP-D. SPR spectroscopy experiments showed that SP-D was able to interact with VACV in a dose-dependent manner and that the carbohydrate recognition domain (CRD) should be implicated because of binding inhibition by sugars and EDTA. In the same manner, a $\mathrm{Ca}^{2+}$-dependent interaction was first observed between SP-D and A27 coated on microtiter plates. The lack of neutralization of virus infection in plaque assay by NCRD and the weak interaction 
observed between A27 and hNCRD suggested that the involvement of NCRD domain alone (trimeric form) is not sufficient whereas the multimerization of NCRD (higher oligomeric form using S proteinHRP) resulted in a marked interaction. The involvement of multimerized NCRD domains could not be confirmed by SPR due to difficulties of interpretation of the data (presence of glycerol in S proteinHRP).

Although it appears clear that efficient binding requires oligomerization of the CRDs, the mechanism of SP-D interaction with A27 was not entirely clarified. On the one hand, the fact that the binding is inhibited by calcium chelation and in the presence of maltose suggests an involvement of the lectin activity of SP-D. On the other hand, the fact that the weak interaction with NCRD was maintained with the E321K mutant devoid of lectin activity and that the A27 protein is not glycosylated favors the hypothesis of a protein-protein interaction. The interaction of SP-D with A27 appears thus different from that of SP-D with HA, known to involve N-linked carbohydrates of the viral protein [61]. It is rather reminiscent of previous data on the interaction of SP-D with the extracellular domain of TLR-2 and -4, showing that N-linked oligosaccharides are not required and suggesting an involvement of amino acid residues close to the ligand binding site of SP-D [19]. Alternatively, binding of the CRD to a ligand such as maltose may induce conformational changes and impair subsequent interaction with A27. Anti-SP-D monoclonal antibodies would be helpful to further identify the SP-D sequence that supports binding to A27 [19]. In the same manner, a mutant of the multimeric SP-D protein with a non-functional NCRD (e.i E321K mutation) would be useful to determine which domain is important for binding to A27.

Among surfactant proteins, SP-D was the only protein able to inhibit viral infection when using a pulmonary cell line and the soluble defense collagens tested (SP-A, MBL and the three human ficolins $(\mathrm{H}, \mathrm{L}$ and $\mathrm{M})$ ) were unable to induce inhibition. However, SPR experiments showed that some of these proteins interacted with A27 (MBL, L-ficolin and M-ficolin). This apparent discrepancy is reminiscent of previous observations of MBL interaction with Ebola virus. Even if MBL could bind, interact and block Ebola envelope glycoprotein-mediated virus binding to DC-SIGN, MBL was unable to directly neutralize the virus without the presence of complement in neutralization assays [62]. In the same manner, neutralization of influenza virus by MBL was complement-dependent [63]. Little information is available concerning the interactions between ficolins and viruses. In contrast, neutralization of viruses by SDP-D was observed in the absence of complement, conditions in which our experiments were performed. It should be mentioned that, contrary to SP-D, interaction of MBL and ficolins with viruses is expected to activate the lectin complement pathway, leading to opsonization of the virus by $\mathrm{C} 3 \mathrm{~b}$ fragments for subsequent phagocytosis.

Inhibition of VACV in an epithelial airway cellular model led us to use a SP-D-deficient mice model. The mortality of VACV-infected mice was increased in the absence of SP-D, suggesting the involvement of SP-D to neutralize VACV infection. Future experiments could be performed by measuring virus titers in lung, cells recruitment [48] [64], pro-inflammatory cytokine production [49] [48] and histopathological changes to explain the difference of mortality between SP-D ${ }^{-/}$and wildtype mice and to address the significance of SP-D in protection against VACV infection. 


\section{Experimental Section}

\subsection{Cells and viruses}

A549 cells (human lung carcinoma cell line, ATCC CCL-185) were grown in F12K medium (Gibco). BHK-21 cells (hamster kidney cells, ATCC CCL 10) were grown in Glasgow minimum essential medium (Gibco) supplemented with 10\% tryptose phosphate (Sigma) and $50 \mathrm{mM}$ HEPES (Gibco). Vero cells (African green monkey kidney cells, ATCC CCL 81) were grown in M199 medium (Gibco). For cell culture, all media were supplemented with $10 \%$ inactivated fetal calf serum (FCS), whereas medium for infection was supplemented with $5 \%$ FCS and $1 \%$ antibiotics $(100 \mathrm{U} / \mathrm{mL}$ of penicillin and $100 \mu \mathrm{g} / \mathrm{mL}$ of streptomycin, Gibco). Cells were cultured at $37^{\circ} \mathrm{C}$ in a $5 \% \mathrm{CO}_{2}$ atmosphere. Cytotoxicity was determined by trypan blue staining and cell counting. The vaccinia virus Western Reserve strain (VACV-WR) was obtained from the ATCC (ATCC VR-119), the firstgeneration Lister smallpox vaccine (VACV-List, X55-33) was provided by the French health authorities and the vaccinia virus IHD-J strain (VACV-IHDJ) was obtained from the ATCC (ATCC VR-156). All virus strains were produced in BHK-21 cells, intracellular mature viruses were purified using sucrose density gradient centrifugation as previously described [65]. Virus was stored in $10 \mathrm{mM}$ Tris- $\mathrm{HCl}(\mathrm{pH} 8)$ at $-80^{\circ} \mathrm{C}$. Virus productions were titrated in Vero and A549 cells. Before infection, cells were rinsed and infected with virus in culture medium supplemented with $0.5 \%$ FCS and $1 \%$ antibiotics. Purified viruses were inactivated (iVACV) for some experiments using a previously described protocol [66]. Briefly, $100 \mu \mathrm{L}$ were mixed with $1 \mu \mathrm{L}$ Psoralene solution (Sigma, $1 \mathrm{mg} / \mathrm{mL}$ in DMSO) and exposed during 1 hour to an UV light $(365 \mathrm{~nm})$ in a tissue culture plate 48 multi-wells plate. Equivalent titer of $\mathrm{iVACV}$ was $2 \times 10^{10}$ plaque forming units (PFU)/mL.

\subsection{Reagents}

Rabbit anti-surfactant antibodies raised against SP-A and SP-D proteins were purchased from Millipore (AB3420 and AB3434, respectively). Rabbit anti-vaccinia whole virus antibody was purchased from Fitzgerald-Interchim (20VR-69) and both peroxydase-conjugated goat anti-rabbit and anti-mouse IgG antibodies were purchased from Jackson ImmunoResearch. Mouse monoclonal antiHis antibody was purchased from Qiagen (34 660). The mouse monoclonal anti-A27 antibody (5B4) was obtained from C.P Czerny and the mouse monoclonal anti-VACV antibody (B608M) was purchased from Abcam (Ab48569). Peptide:N-glycosidase F (PNGase F) was purchased from Sigma (P7367). A mix of recombinant HA proteins of IAV were obtained from Vaxigrip® (A/Brisbane/59/2007 (H1N1); A/Brisbane/10/2007 (H3N2); B/Florida/4/2006). Predicted molecular size of HA (trimeric protein) was $180 \mathrm{kDa}$ (extracellular domain). S protein-HRP conjugate was purchased from EMD Chemicals, Inc (69047-3).

\subsection{Recombinant surfactant proteins}

Recombinant human SP-D dodecamers were expressed in CHO-K1 cells and purified as previously described [55]. Recombinant trimeric neck + carbohydrate recognition domain fusion proteins (NCRDs) from human (hNCRD and the E321K mutant (mutNCRD)) and rat (rNCRD) species were 
expressed in bacteria and purified as previously described [57] [50]. All preparations used for these studies had low endotoxin (45.2 ng LPS/mg of RhSP-D protein; $20 \mathrm{ng}$ LPS/mg of hNCRD; $0.56 \mathrm{ng}$ LPS/mg of rNCRD; 0.27 ng LPS/mg of mutNCRD). AP-SP-A was a kind gift from Dr J.R. Wright (Duke University, Durham, USA). Recombinant RhSP-A was kindly provided by Dr F. McCormack (University of Cincinnati, Cincinnati, USA). The molecular size of proteins was estimated as followed: $516 \mathrm{kDa}$ for RhSP-D (composed of twelve identical polypeptides of $43 \mathrm{kDa}$ ) and $72 \mathrm{kDa}$ for both hNCRD and mutNCRD (composed of three identical CRD domain of $24 \mathrm{kDa}$ ).

\subsection{Other recombinant proteins}

Human recombinant wild-type M-ficolin was expressed in S2 insect cells and purified as described previously [67]. L-ficolin was purified from serum as described previously [68]. Recombinant human MBL and H-ficolin were produced in CHO cells and purified as described by Teillet et al. [69] and Lacroix et al. [70], respectively.

\subsection{A27 viral protein expression and purification}

The gene coding for full length A27 protein $(A 27 L)$ was amplified from Lister strain of VACV (Pourquier vaccine) using the following primers: A27 sense primer: 5'GGGGACAAGTTTGTACAAAAAAGCAGGCTTAATGGACGGAACTCTTTT3' and A27 antisense primer: 5'GGGGACCACTTTGTACAAGAAAGCTGGGTTTTACTCATAT

GGACGCCG3'. A27L construct was finally cloned in $\mathrm{pDEST}^{\mathrm{TM}} 17$ (Invitrogen, Gateway technology) using the following primers: attB1-A27LS :

5'GGGGACAAGTTTGTACAAAAAAGCAGGCTTAATGGACGGAACTCTTTT 3' et attB2A27LR : 5'GGGGACCACTTTGTACAAGAAAGCTGGGTTTTACTCATATGGACGCCG 3' and transformed in BL21 (DE3) pLysS. The recombinant A27 protein (rA27) contained an N-terminal Histag by analogy with previous studies showing that an $\mathrm{N}$-terminal $\mathrm{T} 7$ tag peptide did not interfere with the function of the corresponding A27 construct [36-38]. Colonies were used to inoculate $1 \mathrm{~L}$ of LB containing appropriate antibiotics. Cells were grown in shakers at appropriate temperature $\left(37^{\circ} \mathrm{C}\right)$ and speed $(200 \mathrm{rpm})$ until reaching $0.6 \mathrm{OD}$ at $600 \mathrm{~nm}$. Expression was induced with $1 \mathrm{mM}$ final concentration of IPTG for 4.5 hours at $37^{\circ} \mathrm{C}$. Pellets were harvested after centrifugation $(10000 \mathrm{~g}, 5$ min, $4^{\circ} \mathrm{C}$ ). They were resuspended in lysis buffer (Tris-HCl $1.5 \mathrm{M}, \mathrm{pH} 7.3$ ), then sonicated and supernatant was harvested. Recombinant N-terminal-His tagged protein was loaded on a His Trap $^{\text {TM }}$ HP column (Amersham Biosciences) and eluted using buffer containing $20 \mathrm{mM}$ sodium phosphate, $500 \mathrm{mM} \mathrm{NaCl}$ and $500 \mathrm{mM}$ imidazole. Purified protein was dialyzed overnight against PBS and quantified using Bradford assay. $240 \mu \mathrm{g}$ of purified rA27 (Quick Start Bradford Protein Assay) was obtained from $1 \mathrm{~L}$ of induced bacteria. The expected amino acid sequence of rA27 was MSYYHHHHHHLESTSLYKKAGLMDGTLFPGDDDLAIPATEFFSTKAAKKPEAKREAIVKADE DDNEETLKQRLTNLEKKITNVTTKFEQIEKCCKRNDEVLFRLENHAETLRAAMISLAKKIDVQ

TGRRPYE, underlined residues corresponding to A27. The monomeric and trimeric forms of the A27 protein were detected by electrophoresis on a $12 \%$ SDS-polyacrylamide gel under reducing and nonreducing conditions, respectively, and protein profiles revealed by western-blot analysis and ECL detection and autoradiography using a mouse monoclonal anti-His antibody. 


\subsection{A27 SDS-PAGE and western-blot analyses}

A27 recombinant protein was subjected to SDS-PAGE (12\%) under reducing and non-reducing conditions. Using western-blot method, A27 protein was revealed using an anti His antibody and a HRP-labeled goat anti-mouse IgG antibody. The peroxidase reaction was assessed by using ECL. The purified recombinant A27 protein $(0.5 \mu \mathrm{g})$ was digested by $15 \mathrm{U}$ peptide:N-glycosidase F (PNGase F) for 10 hours at $26^{\circ} \mathrm{C}$.

\subsection{Surfactant protein interaction with VACV strains by overlay assay}

Purified mature viruses of VACV-WR, VACV-List and VACV-IHDJ strains were dotted on membranes. Duplicates of viral solutions ( $2 \mu \mathrm{g} / \mathrm{spot}$, Bradford virus titration) were spotted onto HybondC-extra nitrocellulose membranes (Amersham) and allowed to dry in the dark at room temperature (RT) for one hour. Membranes were blocked for one hour at RT in TBS containing $0.5 \%$ Tween 20, $\mathrm{CaCl}_{2} 5 \mathrm{mM}$ and $3 \%$ fatty acid-free BSA (Sigma). The membranes were then incubated overnight at RT in the same buffer containing $1 \mu \mathrm{g} / \mathrm{mL}$ surfactant proteins. The membranes were washed three times for $10 \mathrm{~min}$ and then incubated for $1 \mathrm{~h}$ at room temperature with the rabbit anti-SPA or anti-SP-D antibody (1/1000 containing 3\% BSA). After four 20-min washes, the membranes were incubated for $1 \mathrm{~h}$ with anti-rabbit horseradish peroxidase conjugate (1/10000 dilution). Finally, after six 10-min washes, the interactions were detected by enhanced chemiluminescence (ECL).

\section{8. hNCRD interaction with A27 by overlay assay}

Purified A27 and HA (1 $\mu \mathrm{g} / \mathrm{spot})$ were dotted onto HybondC-extra nitrocellulose membranes (Amersham). Membranes were blocked for 1 hour at RT in TBS containing $0.05 \%$ Tween $20, \mathrm{CaCl}_{2}$ $10 \mathrm{mM}$ and 5\% milk. A27 was preincubated with mAbs (clone 5B4, Abcam (B608M) and mouse Ig) for 30 minutes at $37^{\circ} \mathrm{C}$ at $10 \mu \mathrm{g} / \mathrm{mL}$. The membrane was then incubated overnight at $4{ }^{\circ} \mathrm{C}$ in the same buffer containing $5 \mu \mathrm{g} / \mathrm{mL}$ hNCRD. The membranes were washed three times for $20 \mathrm{~min}$ and then incubated for $1 \mathrm{~h}$ at room temperature with the S protein-HRP antibody (1/10,000). After three 20-min washes, interaction was detected by enhanced chemiluminescence (ECL).

\subsection{Lectins-virus infection inhibition assay}

A549 cells were seeded to obtain confluent plates after 48 hours of culture in 12 multi-wells plates. VACV-WR was incubated with $0.6 \mu \mathrm{g}$ of SP-D, MBL, ficolins or $2 \mu \mathrm{g}$ of human, rat and mutated E321K human NCRD for 1 hour at $37^{\circ} \mathrm{C}$. During this time, cells were rinsed with fresh F12K medium $0.5 \%$ FCS and $1 \%$ antibiotics. Then, virus-protein mixes were incubated with cell monolayer (multiplicity of infection, MOI 0.0001 ) at $37^{\circ} \mathrm{C}$ in $5 \% \mathrm{CO}_{2}$ atmosphere during one hour. Cells were rinsed with $0.5 \%$ FCS medium and covered with $1.5 \mathrm{~mL}$ fresh F12K medium $5 \%$ FCS, and cultured for an additional 48 hours. Cells were fixed by adding $0.75 \mathrm{~mL}$ of fixing and staining solution $(0.2 \%$ crystal violet, $4.5 \%$ formaldehyde and $7.5 \%$ ethanol in PBS) per well for 2 hours. Wells were rinsed twice with water and PFU were counted. Experiment was performed three times. Additional experiment was performed at $10 \mu \mathrm{g}$ of human NCRD. 


\subsection{Binding of SP-D to A27 recombinant VACV protein}

A27, HA mix of IAV (Vaxigrip ${ }^{\circledR}$ ), SP-D, hNCRD and mutNCRD (100 ng/well in $100 \mathrm{mM} \mathrm{Na}_{2} \mathrm{CO}_{3}$ $\mathrm{pH}$ 9.6) were coated onto microtiter wells overnight at $4^{\circ} \mathrm{C}$, and nonspecific binding was blocked with PBS buffer without $\mathrm{Ca}$ and $\mathrm{Mg}$ (BioWhittaker) containing 5\% (w/v) fatty acid-free BSA, $0.05 \%$ tween and $5 \mathrm{mM} \mathrm{CaCl}_{2}$ (buffer A) for 1 hour at $37^{\circ} \mathrm{C}$. SP-D $(2.5 \mu \mathrm{g} / \mathrm{mL})$ or NCRD $(5 \mu \mathrm{g} / \mathrm{mL})$ in buffer A was added and incubated at $37^{\circ} \mathrm{C}$ for 2 hours. After the incubation, the wells were washed with buffer $\mathrm{A}$ and further incubated with rabbit anti-SP-D polyclonal antibodies followed by incubation with peroxidase-conjugated goat anti-rabbit IgG antibody. The peroxidase reaction was finally conducted by using TMB substrate (Sigma), and the absorbance at $450 \mathrm{~nm}$ was measured. Some incubations were also performed in the absence of $\mathrm{Ca}^{2+}$.

\subsection{ELISA assay for measurement of binding of NCRDs to A27 recombinant VACV protein}

Binding of trimeric NCRD fusion proteins to A27 protein of VACV was measured as previously described using the S protein-HRP conjugate (Novagen) [53]. In brief, ELISA plates were coated with A27 protein $(10 \mu \mathrm{g} / \mathrm{mL}, 50 \mu \mathrm{L}$ per well) followed by washing and addition of a range $(2,5,7,15$ and $30 \mu \mathrm{g} / \mathrm{mL}$ ) of NCRD alone or NCRD that had been preincubated with S protein-HRP (1:20, concentration). After further washing, S protein-HRP was added to the wells that had only received NCRD (1:5 000, concentration). Binding was detected using peroxidase substrate (TMB, Sigma, France).

\subsection{Electron Microscopy}

Inactivated VACV-WR was incubated with RhSP-D for $1 \mathrm{~h}$ at $37^{\circ} \mathrm{C}$ (vol/vol). Inactivated VACVWR and RhSP-D were used as a control. After incubation $3 \mu \mathrm{l}$ of each sample was adsorbed to a carbon-mica interface. The carbon film with adsorbed protein was floated onto a solution of a $2 \%$ uranyl acetate solution diluted in water. The film was then picked up by a 200 mesh copper EM grid and finally air-dried. The samples were then transferred in an FEI Tecnai electron microscope equipped with a CCD cold stage $2 \times 2 \mathrm{~K}$ camera and observed at $200 \mathrm{Kv}$.

\subsection{Surface plasmon resonance analyses on immobilized SP-D}

Analyses were performed using a Biacore X instrument (GE Healthcare). Recombinant human SP$\mathrm{D}$ and fatty acid-free BSA were diluted to $23 \mu \mathrm{g} / \mathrm{ml}$ in $10 \mathrm{mM} \mathrm{Na}$ acetate, $\mathrm{pH} 5.0$ and $50 \mu \mathrm{g} / \mathrm{ml}$ in 10 $\mathrm{mM} \mathrm{Na}$ acetate, $\mathrm{pH} 4.0$, respectively, and immobilized on the surface of a CM5 sensor chip (GE Healthcare) using the amine coupling chemistry until coupling levels of 10,000 RU (SP-D) and 8,800 RU (BSA) were reached. The running buffer for immobilization was $10 \mathrm{mM}$ Hepes, $150 \mathrm{mM} \mathrm{NaCl}$, 3.4 mM EDTA, pH 7.4 containing $0.005 \%$ surfactant P20 (GE Healthcare). Fifty $\mu 1$ of inactivated WR virus were injected over both SP-D and the blank surface at a flow rate of $5 \mu 1 / \mathrm{min}$ in $20 \mathrm{mM}$ Hepes,

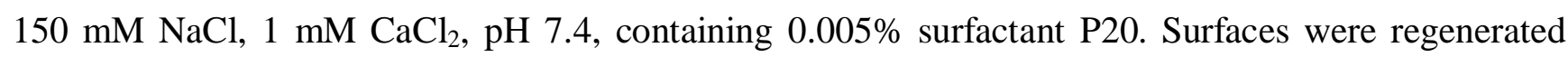
with $10 \mu \mathrm{l}$ of $10 \mathrm{mM}$ EDTA, pH 7.4, with an additional injection of $1 \mathrm{M} \mathrm{NaCl}, 10 \mathrm{mM}$ EDTA, pH 7.4, when needed. The binding curves shown are obtained after automatic subtraction of the signal recorded on the reference surface. Injections $(40 \mu \mathrm{l})$ of various concentrations of a mix of IAV 
hemagglutinin (Vaxigrip ${ }^{\circledR}$ ) for kinetic analysis were performed under the same conditions, except that the flow rate was set at $20 \mu \mathrm{l} / \mathrm{min}$. Experiments were performed twice.

\subsection{Surface plasmon resonance analyses on immobilized A27 viral protein}

Recombinant viral A27 and fatty acid-free BSA were diluted to 26 and $20 \mu \mathrm{g} / \mathrm{ml}$, respectively, in 10 $\mathrm{mM} \mathrm{Na}$ acetate, $\mathrm{pH} 3.5$, respectively and immobilized on the surface of a CM5 sensor chip using the amine coupling chemistry until coupling levels of 600 RU (A27) and 1400 RU (BSA) were reached. Forty $\mu 1$ of various lectins (SP-D, SP-A, MBL, ficolins) were injected over both A27 and the blank surface at a flow rate of $20 \mu \mathrm{l} / \mathrm{min}$ in $20 \mathrm{mM}$ Hepes, $150 \mathrm{mM} \mathrm{NaCl}, 1 \mathrm{mM} \mathrm{CaCl}$, pH 7.4, containing $0.005 \%$ surfactant P20 (GE Healthcare). Surfaces were regenerated with $10 \mu 1$ of $1 \mathrm{M} \mathrm{NaCl,} 10 \mathrm{mM}$ EDTA, pH 7.4, with an additional injection of $0.1 \%$ SDS, when needed. The binding curves shown were obtained after automatic subtraction of the signal recorded on the reference surface. Experiments were performed twice.

\subsection{Surface Plasmon resonance data evaluation}

Kinetic data were analyzed by global fitting to a 1:1 Langmuir binding model of both the association and dissociation phases for at least five concentrations simultaneously (1.7-13.7 nM SP-D, 0.5-8 nM hemagglutinin of IAV), using the BIAevaluation 3.2 software (GE Healthcare). The apparent equilibrium dissociation constants $\left(K_{\mathrm{D}}\right)$ were calculated from the ratio of the dissociation and association rate constants $\left(k_{\mathrm{d}} / k_{\mathrm{a}}\right)$.

\subsection{Ethics Statement}

Animals were housed according with the French Ethical Committee (Decree 87-848) and European Community Directive 86/609/EEC. Experiments were carried out under the supervision of the "Comité Consultatif pour l'Éthique en Expérimentation Animale". The protocols were approved by the Committee on the Ethics of Animal Experiments of the IRBA-CRSSA (Permit Number 2007/33.01). All efforts were made to minimize suffering.

\subsection{Animals}

National Institutes of Health (NIH) Swiss Black SP-D ${ }^{+/+}$and knocked out SP-D ${ }^{-/}$mice (females and males) were provided from Cincinnati Children's Hospital Medical Center (Ohio, USA) [71] and finally bred in Institute Jean Roget animal facility (La Tronche, France). Mice (four weeks old) were quarantined for one week. General anesthesia was performed by intraperitoneal injection with a mix of ketamine $(100 \mathrm{mg} / \mathrm{kg})$ and atropine $(1.5 \mathrm{mg} / \mathrm{kg})$. Animals were sacrificed when necessary by intraperitoneal injection of pentobarbital $(330 \mathrm{mg} / \mathrm{kg})$. Experiment was performed three times, SP-D ${ }^{-/}$ and SP-D ${ }^{+/+}$infected-mice groups were composed of 13-16; 26-30; $32-26$ animals, respectively. Control groups, SP-D ${ }^{-/}$and SP-D ${ }^{+/+}$non-infected mice, were composed of 5 animals. Mice were housed in filtered boxes and maintained under specific pathogen-free conditions. Experiments were 
performed in accordance with national guidelines governing use of laboratory animals and were approved by the local animal care and use committee (Permit number 2007/33.1).

\subsection{VACV-WR intranasal infection model}

The infectious dose that was lethal to $50 \%$ of mice $\left(\mathrm{LD}_{50}\right)$ was determined by infecting black Swiss $\mathrm{SP}^{-\mathrm{D}^{+/+}}$mice (from NIH) with VACV-WR. Mice (five weeks old, 6 mice per group) were infected intranasally with $25 \mu \mathrm{L}$ of the VACV-WR solution containing multiple dilutions of VACV-WR $(1 \mathrm{x}$ $10^{5}, 5 \times 10^{5}$ and $1 \times 10^{6} \mathrm{PFU} /$ mice). The $\mathrm{LD}_{50}$ of VACV-WR was calculated as $5 \times 10^{5} \mathrm{PFU}$. Purified virus was diluted in F12K medium (Gibco). Mice (five weeks old) were infected intranasally with 25 $\mu \mathrm{L}$ containing $1 \mathrm{LD}_{50}$ and control groups were instilled with $25 \mu \mathrm{L}$ of $\mathrm{F} 12 \mathrm{~K}$ medium. Groups of mice were monitored for mortality daily until 17 days post-infection (p.i).

\subsection{Statistical analysis}

For in vitro studies, the two-tailed unpaired Student's t-test was performed. The animal survival study was analyzed with the Log-Rank test. Values of $p<0.05$ were considered significant.

\section{Conclusions}

We demonstrate in this study that SP-D plays an important role in pulmonary host defense against the variola virus. Using in vitro interactions, we show that SP-D blocked entry of VACV and could provide protection against infection in vivo. Binding to SP-D was mediated by viral protein A27; however the exact mechanism was not entirely elucidated and additional experiments would be undertaken to precisely determine the involvement of NCRD in the interaction. In vivo experiments also supported that SP-D was required for VACV infection. Further studies are needed to address the potential antiviral activity of SP-D and its capacity to modulate inflammatory responses.

\section{Abbreviations}

A27, vaccinia virus A27 membrane protein (14-kDa fusion protein)

$\mathrm{CRD}$, carbohydrate recognition domain

$\mathrm{HA}$, hemagglutinin protein of IAV

IAV, Influenza A virus

MBL, mannan-binding lectin

NCRD, recombinant trimeric neck+CRDs

SP-A, surfactant protein A

SP-D, surfactant protein D

RSV, respiratory syncycial virus

VACV, vaccinia virus

VARV, variola virus 


\section{Acknowledgments}

AP-SP-A was a kind gift from Dr J.R. Wright (Duke University, Durham, USA). Recombinant RhSP-A was kindly gift by Dr F. McCormack (University of Cincinnati, Cincinnati, USA). We thank Dr S. Vigne for recombinant A27 protein, A. Georges for animal technical support and both S. Bendeff and F. Blanquet for animal facilities. We thank C.P Czerny for the 5B4 mouse monoclonal anti-A27 antibody. We thank I. Bally from the IBS platform of the Partnership for Structural Biology for assistance and access to the Biacore facility.

\section{Financial support}

This work was supported by Délégation Générale pour l'Armement (DGA) and the ARAMI association.

\section{Conflict of Interest}

The authors declare no conflict of interest.

\section{References and Notes}

1. Breman, J.G.; Arita, I. The confirmation and maintenance of smallpox eradication. N. Engl. J. Med. 1980, 303, 1263-1273.

2. Sherman, I. W. Twelve diseases that changed our world. Emerg. Infect. Dis. 2008, 14, 866.

3. Dudgeon, J. A. Virus infections of the upper respiratory tract (abridged). Proc. R. Soc. Med. 1969, 62, 1-2.

4. Fenner, F.; Henderson, D.A.; Arita, I.; Jezek, Z.; Ladnyi, I.D. Smallpox and its eradication. WHO: Geneva, 1988; p 1460.

5. Buller, R.M.; Palumbo, G.J. Poxvirus pathogenesis. Microbiol. Rev. 1991, 55, 80-122.

6. Andreeva, A.V.; Kutuzov, M.A.; Voyno-Yasenetskaya, T.A. Regulation of surfactant secretion in alveolar type II cells. Am. J. Physiol. Lung Cell Mol. Physiol. 2007, 293, 259-271.

7. Wustneck, R.; Perez-Gil, J.; Wustneck, N.; Cruz, A.; Fainerman, V.B.; Pison, U. Interfacial properties of pulmonary surfactant layers. Adv. Colloid. Interface. Sci. 2005, 117, 33-58.

8. Haagsman, H.P.; Hogenkamp, A.; van Eijk, M.; Veldhuizen, E.J. Surfactant collectins and innate immunity. Neonatology 2008, 93, 288-294.

9. Haczku, A. Protective role of the lung collectins surfactant protein A and surfactant protein D in airway inflammation. J. Allergy. Clin. Immunol. 2008, 122, 861-879; quiz 880-881.

10. Kishore, U.; Greenhough, T.J.; Waters, P.; Shrive, A.K.; Ghai, R.; Kamran, M.F.; Bernal, A.L.; Reid, K.B.; Madan, T.; Chakraborty, T. Surfactant proteins SP-A and SP-D: structure, function and receptors. Mol. Immunol. 2006, 43, 1293-1315.

11. Holmskov, U.; Malhotra, R.; Sim, R.B.; Jensenius, J.C. Collectins: collagenous C-type lectins of the innate immune defense system. Immunol. Today 1994, 15, 67-74.

12. Sahly, H.; Keisari, Y.; Crouch, E.; Sharon, N.; Ofek, I. Recognition of bacterial surface polysaccharides by lectins of the innate immune system and its contribution to defense against infection: the case of pulmonary pathogens. Infect. Immun. 2008, 76, 1322-1332. 
13. Reading, P.C.; Pickett, D.L.; Tate, M.D.; Whitney, P.G.; Job, E.R.; Brooks, A.G. Loss of a single $\mathrm{N}$-linked glycan from the hemagglutinin of influenza virus is associated with resistance to collectins and increased virulence in mice. Respir. Res. 2009, 10, 117.

14. Crouch, E.; Hartshorn, K.; Ofek, I. Collectins and pulmonary innate immunity. Immunol. Rev. 2000, 173, 52-65.

15. Epstein, J.; Eichbaum, Q.; Sheriff, S.; Ezekowitz, R.A. The collectins in innate immunity. Curr. Opin. Immunol. 1996, 8, 29-35.

16. Reading, P.C.; Morey, L.S.; Crouch, E.C.; Anders, E.M. Collectin-mediated antiviral host defense of the lung: evidence from influenza virus infection of mice. J. Virol. 1997, 71, 8204-8212.

17. Seaton, B.A.; Crouch, E.C.; McCormack, F.X.; Head, J.F.; Hartshorn, K.L.; Mendelsohn, R. Review: Structural determinants of pattern recognition by lung collectins. Innate. Immun. 2010, 16, 143-150.

18. Hakansson, K.; Reid, K.B. Collectin structure: a review. Protein Sci. 2000, 9, 1607-1617.

19. Ohya, M.; Nishitani, C.; Sano, H.; Yamada, C.; Mitsuzawa, H.; Shimizu, T.; Saito, T.; Smith, K.; Crouch, E.; Kuroki, Y. Human pulmonary surfactant protein D binds the extracellular domains of Toll-like receptors 2 and 4 through the carbohydrate recognition domain by a mechanism different from its binding to phosphatidylinositol and lipopolysaccharide. Biochemistry 2006, 45, 86578664.

20. Nie, X.; Nishitani, C.; Yamazoe, M.; Ariki, S.; Takahashi, M.; Shimizu, T.; Mitsuzawa, H.; Sawada, K.; Smith, K.; Crouch, E.; Nagae, H.; Takahashi, H.; Kuroki, Y. Pulmonary surfactant protein D binds MD-2 through the carbohydrate recognition domain. Biochemistry 2008, 47, 12878-12885.

21. DeSilva, N.S.; Ofek, I.; Crouch, E.C. Interactions of surfactant protein D with fatty acids. Am. J. Respir. Cell Mol. Biol. 2003, 29, 757-770.

22. Grubor, B.; Meyerholz, D.K.; Ackermann, M.R. Collectins and cationic antimicrobial peptides of the respiratory epithelia. Vet. Pathol. 2006, 43, 595-612.

23. Hartshorn, K.L.; Crouch, E.C.; White, M.R.; Eggleton, P.; Tauber, A.I.; Chang, D.; Sastry, K. Evidence for a protective role of pulmonary surfactant protein D (SP-D) against influenza A viruses. J. Clin. Invest. 1994, 94, 311-319.

24. Hickling, T.P.; Bright, H.; Wing, K.; Gower, D.; Martin, S.L.; Sim, R.B.; Malhotra, R. A recombinant trimeric surfactant protein $\mathrm{D}$ carbohydrate recognition domain inhibits respiratory syncytial virus infection in vitro and in vivo. Eur. J. Immunol. 1999, 29, 3478-3484.

25. Griese, M. Respiratory syncytial virus and pulmonary surfactant. Viral. Immunol. 2002, 15, 357363.

26. LeVine, A.M.; Elliott, J.; Whitsett, J.A.; Srikiatkhachorn, A.; Crouch, E.; DeSilva, N.; Korfhagen, T. Surfactant protein-d enhances phagocytosis and pulmonary clearance of respiratory syncytial virus. Am. J. Respir. Cell Mol. Biol. 2004, 31, 193-199.

27. Hartshorn, K.L.; White, M.R.; Tecle, T.; Holmskov, U.; Crouch, E.C. Innate defense against influenza A virus: activity of human neutrophil defensins and interactions of defensins with surfactant protein D. J. Immunol. 2006, 176, 6962-6972.

28. White, M.R.; Boland, P.; Tecle, T.; Gantz, D.; Sorenson, G.; Tornoe, I.; Holmskov, U.; McDonald, B.; Crouch, E.C.; Hartshorn, K.L. Enhancement of antiviral activity of collectin 
trimers through cross-linking and mutagenesis of the carbohydrate recognition domain. J. Innate. Immun. 2010, 2, 267-279.

29. Qi, L.; Kash, J.C.; Dugan, V.G.; Jagger, B.W.; Lau, Y.F.; Sheng, Z.M.; Crouch, E.C.; Hartshorn, K.L.; Taubenberger, J.K. The ability of pandemic influenza virus hemagglutinins to induce lower respiratory pathology is associated with decreased surfactant protein D binding. Virology 2011, 412, 426-434.

30. Kongchanagul, A.; Suptawiwat, O.; Boonarkart, C.; Kitphati, R.; Puthavathana, P.; Uiprasertkul, M.; Auewarakul, P. Decreased expression of surfactant protein D mRNA in human lungs in fatal cases of H5N1 avian influenza. J. Med. Virol. 2011, 83, 1410-1417.

31. Hartshorn, K.L.; White, M.R.; Voelker, D.R.; Coburn, J.; Zaner, K.; Crouch, E.C. Mechanism of binding of surfactant protein D to influenza A viruses: importance of binding to haemagglutinin to antiviral activity. Biochem. J. 2000, 351, 449-458.

32. Vigerust, D.J.; Ulett, K.B.; Boyd, K.L.; Madsen, J.; Hawgood, S.; McCullers, J.A. N-linked glycosylation attenuates H3N2 influenza viruses. J. Virol. 2007, 81, 8593-8600.

33. Hartshorn, K.L.; Webby, R.; White, M.R.; Tecle, T.; Pan, C.; Boucher, S.; Moreland, R.J.; Crouch, E.C.; Scheule, R.K. Role of viral hemagglutinin glycosylation in anti-influenza activities of recombinant surfactant protein D. Respir. Res. 2008, 9, 65.

34. Job, E.R.; Deng, Y.M.; Tate, M.D.; Bottazzi, B.; Crouch, E.C.; Dean, M.M.; Mantovani, A.; Brooks, A.G.; Reading, P.C. Pandemic H1N1 influenza A viruses are resistant to the antiviral activities of innate immune proteins of the collectin and pentraxin superfamilies. J. Immunol. 2010, 185, 4284-4291.

35. Rodriguez, J.F.; Esteban, M. Mapping and nucleotide sequence of the vaccinia virus gene that encodes a 14-kilodalton fusion protein. J. Virol. 1987, 61, 3550-3554.

36. Doms, R.W.; Blumenthal, R.; Moss, B. Fusion of intra- and extracellular forms of vaccinia virus with the cell membrane. J. Virol. 1990, 64, 4884-4892.

37. Gong, S.C.; Lai, C.F.; Esteban, M. Vaccinia virus induces cell fusion at acid $\mathrm{pH}$ and this activity is mediated by the N-terminus of the 14-kDa virus envelope protein. Virology 1990, 178, 81-91.

38. Kochan, G.; Escors, D.; Gonzalez, J.M.; Casasnovas, J.M.; Esteban, M. Membrane cell fusion activity of the vaccinia virus A17-A27 protein complex. Cell Microbiol. 2008, 10, 149-164.

39. Meyer, H.; Osterrieder, N.; Czerny, C.P. Identification of binding sites for neutralizing monoclonal antibodies on the 14-kDa fusion protein of orthopox viruses. Virology 1994, 200, 778-783.

40. Chung, C.S.; Hsiao, J.C.; Chang, Y.S.; Chang, W. A27L protein mediates vaccinia virus interaction with cell surface heparan sulfate. J. Virol. 1998, 72, 1577-1585.

41. Hsiao, J.C.; Chung, C.S.; Chang, W. Cell surface proteoglycans are necessary for A27L proteinmediated cell fusion: identification of the N-terminal region of $\mathrm{A} 27 \mathrm{~L}$ protein as the glycosaminoglycan-binding domain. J. Virol. 1998, 72, 8374-8379.

42. Perino, J.; Foo, C.H.; Spehner, D.; Cohen, G.H.; Eisenberg, R.J.; Crance, J.M.; Favier, A.L. Role of sulfatide in vaccinia virus infection. Biol. Cell 2011, 103, 319-331.

43. Ho, Y.; Hsiao, J.C.; Yang, M.H.; Chung, C.S.; Peng, Y.C.; Lin, T.H.; Chang, W.; Tzou, D.L. The Oligomeric Structure of Vaccinia Viral Envelope Protein A27L is Essential for Binding to Heparin 
and Heparan Sulfates on Cell Surfaces: A Structural and Functional Approach Using Site-specific Mutagenesis. J. Mol. Biol. 2005, 349, 1060-1071.

44. Vazquez, M.I.; Rivas, G.; Cregut, D.; Serrano, L.; Esteban, M. The vaccinia virus 14-kilodalton (A27L) fusion protein forms a triple coiled-coil structure and interacts with the 21-kilodalton (A17L) virus membrane protein through a C-terminal alpha-helix. J. Virol. 1998, 72, 1012610137.

45. Vazquez, M.I.; Esteban, M. Identification of functional domains in the 14-kilodalton envelope protein (A27L) of vaccinia virus. J. Virol. 1999, 73, 9098-9109.

46. Cross, K.J.; Langley, W.A.; Russell, R.J.; Skehel, J.J.; Steinhauer, D.A. Composition and functions of the influenza fusion peptide. Protein Pept. Letter. 2009, 16, 766-778.

47. Hartshorn, K.; Chang, D.; Rust, K.; White, M.; Heuser, J.; Crouch, E. Interactions of recombinant human pulmonary surfactant protein D and SP-D multimers with influenza A. Am. J. Physiol. 1996, 271, 753-762.

48. LeVine, A.M.; Whitsett, J.A.; Hartshorn, K.L.; Crouch, E.C.; Korfhagen, T.R. Surfactant protein D enhances clearance of influenza A virus from the lung in vivo. J. Immunol. 2001, 167, 58685873.

49. Hawgood, S.; Brown, C.; Edmondson, J.; Stumbaugh, A.; Allen, L.; Goerke, J.; Clark, H.; Poulain, F. Pulmonary collectins modulate strain-specific influenza a virus infection and host responses. J. Virol. 2004, 78, 8565-8572.

50. Carlson, T.K.; Torrelles, J.B.; Smith, K.; Horlacher, T.; Castelli, R.; Seeberger, P.H.; Crouch, E.C.; Schlesinger, L.S. Critical role of amino acid position 343 of surfactant protein-D in the selective binding of glycolipids from Mycobacterium tuberculosis. Glycobiology 2009, 19, 14731484.

51. Tecle, T.; White, M.R.; Sorensen, G.; Gantz, D.; Kacak, N.; Holmskov, U.; Smith, K.; Crouch, E.C.; Hartshorn, K.L. Critical role for cross-linking of trimeric lectin domains of surfactant protein $\mathrm{D}$ in antiviral activity against influenza A virus. Biochem. J. 2008, 412, 323-329.

52. Lai, C.F.; Gong, S.C.; Esteban, M. Structural and functional properties of the 14-kDa envelope protein of vaccinia virus synthesized in Escherichia coli. J. Biol. Chem. 1990, 265, 22174-22180.

53. Crouch, E.; Tu, Y.; Briner, D.; McDonald, B.; Smith, K.; Holmskov, U.; Hartshorn, K. Ligand specificity of human surfactant protein D: expression of a mutant trimeric collectin that shows enhanced interactions with influenza A virus. J. Biol. Chem. 2005, 280, 17046-17056.

54. Crouch, E.; Persson, A.; Chang, D.; Heuser, J. Molecular structure of pulmonary surfactant protein D (SP-D). J. Biol. Chem. 1994, 269, 17311-17319.

55. Crouch, E.; Chang, D.; Rust, K.; Persson, A.; Heuser, J. Recombinant pulmonary surfactant protein D. Post-translational modification and molecular assembly. J. Biol. Chem. 1994, 269, 15808-15813.

56. Fenner, F. The biological characters of several strains of vaccinia, cowpox and rabbitpox viruses. Virology 1958, 5, 502-529.

57. Crouch, E.C.; Smith, K.; McDonald, B.; Briner, D.; Linders, B.; McDonald, J.; Holmskov, U.; Head, J.; Hartshorn, K. Species differences in the carbohydrate binding preferences of surfactant protein D. Am. J. Respir. Cell Mol. Biol. 2006, 35, 84-94. 
58. Malhotra, R.; Haurum, J.S.; Thiel, S.; Sim, R.B. Binding of human collectins (SP-A and MBP) to influenza virus. Biochem. J. 1994, 304, 455-461.

59. Hartshorn, K.L.; White, M.R.; Tecle, T.; Sorensen, G.; Holmskov, U.; Crouch, E.C. Viral aggregating and opsonizing activity in collectin trimers. Am. J. Physiol. Lung Cell Mol. Physiol. 2010, 298, 79-88.

60. Hartshorn, K.L.; White, M.R.; Rynkiewicz, M.; Sorensen, G.; Holmskov, U.; Head, J.; Crouch, E.C. Monoclonal antibody-assisted structure-function analysis of the carbohydrate recognition domain of surfactant protein D. Am. J. Physiol. Lung. Cell Mol. Physiol. 2010, 299, 384-392.

61. Crouch, E.; Nikolaidis, N.; McCormack, F.X.; McDonald, B.; Allen, K.; Rynkiewicz, M.J.; Cafarella, T.M.; White, M.; Lewnard, K.; Leymarie, N.; Zaia, J.; Seaton, B.A.; Hartshorn, K.L. Mutagenesis of surfactant protein D informed by evolution and $\mathrm{x}$-ray crystallography enhances defenses against influenza A virus in vivo. J. Biol. Chem. 2011, 286, 40681-40692.

62. Ji, X.; Olinger, G.G.; Aris, S.; Chen, Y.; Gewurz, H.; Spear, G.T. Mannose-binding lectin binds to Ebola and Marburg envelope glycoproteins, resulting in blocking of virus interaction with DCSIGN and complement-mediated virus neutralization. J. Gen. Virol. 2005, 86, 2535-2542.

63. Anders, E.M.; Hartley, C.A.; Reading, P.C.; Ezekowitz, R.A. Complement-dependent neutralization of influenza virus by a serum mannose-binding lectin. J. Gen. Virol. 1994, 75, 615622.

64. Lemos, M.P.; McKinney, J.; Rhee, K.Y., Dispensability of surfactant proteins A and D in immune control of Mycobacterium tuberculosis infection following aerosol challenge of mice. Infect. Immun. 2011, 79, 1077-1085.

65. Lee, H.J.; Essani, K.; Smith, G.L. The genome sequence of Yaba-like disease virus, a yatapoxvirus. Virology 2001, 281, 170-192.

66. Tsung, K.; Yim, J.H.; Marti, W.; Buller, R.M.; Norton, J.A. Gene expression and cytopathic effect of vaccinia virus inactivated by psoralen and long-wave UV light. J. Virol. 1996, 70, 165-171.

67. Gout, E.; Garlatti, V.; Smith, D.F.; Lacroix, M.; Dumestre-Perard, C.; Lunardi, T.; Martin, L.; Cesbron, J.Y.; Arlaud, G.J.; Gaboriaud, C.; Thielens, N.M. Carbohydrate recognition properties of human ficolins: glycan array screening reveals the sialic acid binding specificity of M-ficolin. $J$. Biol. Chem. 2010, 285, 6612-6622.

68. Teillet, F.; Gaboriaud, C.; Lacroix, M.; Martin, L.; Arlaud, G.J.; Thielens, N.M. Crystal structure of the CUB1-EGF-CUB2 domain of human MASP-1/3 and identification of its interaction sites with mannan-binding lectin and ficolins. J. Biol. Chem. 2008, 283, 25715-25724.

69. Teillet, F.; Lacroix, M.; Thiel, S.; Weilguny, D.; Agger, T.; Arlaud, G.J.; Thielens, N.M. Identification of the site of human mannan-binding lectin involved in the interaction with its partner serine proteases: the essential role of Lys55. J. Immunol. 2007, 178, 5710-5716.

70. Lacroix, M.; Dumestre-Perard, C.; Schoehn, G.; Houen, G.; Cesbron, J.Y.; Arlaud, G.J.; Thielens, N.M. Residue Lys57 in the collagen-like region of human L-ficolin and its counterpart Lys47 in $\mathrm{H}$-ficolin play a key role in the interaction with the mannan-binding lectin-associated serine proteases and the collectin receptor calreticulin. J. Immunol. 2009, 182, 456-465. 
71. Korfhagen, T.R.; Sheftelyevich, V.; Burhans, M.S.; Bruno, M.D.; Ross, G.F.; Wert, S.E.; Stahlman, M.T.; Jobe, A.H.; Ikegami, M.; Whitsett, J.A.; Fisher, J.H. Surfactant protein-D regulates surfactant phospholipid homeostasis in vivo. J. Biol. Chem. 1998, 273, 28438-28443.

(C) 2013 by the authors; licensee MDPI, Basel, Switzerland. This article is an open access article distributed under the terms and conditions of the Creative Commons Attribution license (http://creativecommons.org/licenses/by/3.0/). 